\title{
The impact of human resource management on business process improvement: an analysis within the MSMEs of the textile and clothing industry
}

\section{Uticaj menadžmenta ljudskih resursa na poboljšanje poslovnih procesa: analiza u okviru MMSP tekstilne i odevne industrije}

\author{
Andrea Dobrosavljević ${ }^{a *}$, Snežana Uroševićb \\ ${ }^{a}$ Independent researcher \\ ${ }^{\mathrm{b}}$ University of Belgrade, Tehnical Faculty in Bor, Deparmnet of Management, Bor, Serbia
}

\begin{abstract}
Business process improvement is necessary given the need to satisfy consumers by delivering value-added products and services. The textile and clothing industry in the age of consumerism of textile and clothing products is facing the challenge of the constant need to meet and exceed consumer expectations. Establishing the practice of continuous business process improvement, especially within the micro, small and medium enterprises (MSMEs) of the textile and clothing industry, as the largest group of companies, is of particular importance in resisting these challenges. As the textile and clothing industry is labor-intensive and a large number of processes operate on the basis of direct engagement of human resources, there is a need to examine the impact of human resource management on the establishment of the practice of business process improvement in MSMEs. Within this paper, the impact of human resource management on the improvement of business processes was examined by applying regression analysis.
\end{abstract}

Keywords: human resource management (HRM), business processes, business process improvement (BPI), micro, small and medium enterprises (MSMEs), textile and clothing industry

Sažetak: Poboljšanje poslovnih procesa je neohodno imajući u vidu potrebu za zadovoljenjem potrošača isporukom proizvoda i usluga dodatne vrednosti. Tekstilna i odevna industrija u dobu konzumerizma tekstilnih i odevnih proizvoda pred izazovom je konstantne potrebe za zadovoljenjem i nadmašivanjem očekivanja potrošača. Uspostavljanje prakse kontinuiranog poboljšanja poslovnih procesa, posebno u okviru mikro, malih i srednjih preduzeća (MMSP) tekstilne i odevne industrije, kao najbrojnije grupe predzeća, od posebnog je značaja u borbi

${ }^{*}$ Corresponding author

E-mail address: an.dobrosavljevic@gmail.com

This is an open access paper under the license (c) (1) () 
protiv ovih izazova. Kako je tekstilna i odevna industrija radno-intenzivna $i$ veliki broj procesa funkcioniše na bazi direktnog angažovanja ljudskih resursa javlja se potreba za ispitivanjem uticaja upravljanja njima na uspostavljanje prakse poboljšanja poslovnih procesa u MMSP. U okviru ovog rada uticaj upravljanja ljudskih resursa na poboljšanje poslovnih procesa ispitan je primenom regresione analize.

Ključne reči: upravljanje ljudskim resursima, poslovni procesi, poboljšanje poslovnih procesa, mikro, mala i srednja preduzeća (MMSP), tekstilna i odevna industrija

\section{Introduction}

In contemporary business conditions, the establishment of business process improvement (BPI) is of special importance, bearing in mind that within processes additional value for consumers is created. Outcomes of business processes as well as the process of BPI depend on various factors among which one of the main might be the human resource management (HRM) as BPI assumes high degree of human resources involvement in operations concerning systematic and continuous improvement of processes (Brajer-Marczak, 2014). Beerepoot et al. (2019) find that the organization size plays an important role when it comes to determination of appropriate BPI activities. Within this paper micro, small and medium enterprises (MSMEs) within textile and clothing industry in the regions of Southern and Eastern Serbia are taken into consideration. Observing the business processes of this group of organizations, it is possible to notice two basic characteristics, the limitation in the number of human resources (Saleh \& Ndubisi, 2006; Demirbag et al., 2006) and the intensity of work in operations within the processes that are still performed manually in a large number of organizations (Battaglia et al., 2014; Pazilov et al., 2020). Textile and clothing industries are among the labor-intensive manufacturing industries (Park \& Andersen, 1991). Involvement of human resources in processes within MSMEs of textile and clothing industry is direct, high and active, as these processes are characterized by high degree of manual labor in various operations (Dobrosavljević, 2019). Thus, it can also be said that the achievement of business success is under the significant influence of human resources and proper HRM (Holland et al., 2007). Given leads to the definition of the basic assumption within this paper, that HRM can be regarded as a factor of strong and positive impact on BPI in textile and clothing industry MSMEs. This group of organizations is observed within this paper because the former picture of the textile and clothing industry in Serbia included the existence of a significant number of large companies, but today's picture, according to the report of the Republic Statistical Office of Serbia, shows a significant presence of micro, small and medium organizations in this area of business (Statistical Yearbook of the Republic of Serbia, 2018). From that side, it can be said that it is important to look at the business of this group of organizations and the HRM as impactful factor on improving business processes in them.

Within this paper the theoretical background of the HRM and BPI is covered. Theoretical part of the paper covers consideration of importance of BPI in general, HRM as a potential factor of BPI and the nature of business processes within textile and clothing industry MSMEs. Then, an impact analysis is performed on a sample of 210 respondents from textile and clothing industry MSMEs form Southern and Eastern Serbia, to test the main assumption. 
The impact of human resource management on business process improvement: an analysis within the MSMEs of the textile and clothing industry

\section{The importance of business process improvement}

Business process improvement (BPI) refers to the business initiative (Holtzman, 2011). It aims to identify strategic goals and targets, while improving business processes of an organization in order to satisfy customers needs and expectations to a greater extent. This initiative refers to the development, reform, advancement of process quality and effectiveness, while lowering the costs (Damij et al., 2008). Mohammady Garfamy (2011) stresses out that there are two dimensions of BPI that have to be considered, as this practice can be regarded taking into consideration internal and external aspects. These dimensions refer to improvement initiative and customer focus. Increased efficiency of the business processes, improved customer service, information and data flow, effective implementation of information technology and reduction of repetitive activities within processes arise as a result of BPI (Damij et al., 2008). The main topics under the umbrella of BPI are focused on continuous BPI, business process reengineering and benchmarking of business processes (Lee \& Chuah, 2001). As Sallos et al. (2017) confirm, BPI initiatives range from marginal continuous improvements to business process reengineering.

When organizations focus on BPI, they become learning organizations. This means that the human resources involved in business processes learn about their responsibilities for all the sequences of logically arranged activities (Brajer-Marczak, 2014). Process improvement initiatives should be supported by knowledge management, as stressed by $\mathrm{Hu}$ et al. (2019). Developing a learning process model while working on process improvement represents the way organizations adapt to a changing business environment (Buckler, 1996). While analyzing the relationship between employees' behavior and BPI Bakotić and Krnić (2017) concluded that there is a positive impact of BPI initiatives on different elements of employees' behavior, as well as on their overall performances.

Methodology through which the BPI can be applied in organizations to enable better focus on business output and customer needs satisfaction is a key issue (McAdam, 1996). Business processes differ from organization to organization, according to the needs of the industry, therefore, the BPI methodology should be adapted to the business conditions of individual organizations (Rashid \& Ahmad, 2013). Gowen II and Johnson (2011) find that BPI deployment in different stages of organizational change trigger the increase of competitive advantage.

Schenkel et al. (2019) highlight that process improvements represent an important source of growth and profitability of small and medium-sized enterprises (SMEs). Large companies are more likely than SMEs to implement the initiatives of BPI, but the SMEs would as well benefit of adequate implementation of these initiatives (McGovern et al., 2017). Iqbal et al. (2016) find process improvement to be critical for enhancement of SMEs business success. When launching any BPI initiative, the support of top management stands out as one of the more significant success factors, which is especially important for SMEs and micro enterprises where the owner is the manager and has decisive role in implementation of any management initiative (Manfreda et al., 2014; Demirbas et al., 2011). The issue of improving business 
processes in the clothing industry is addressed by Slović et al. (2015) who develop a model of continuous process improvements that starts with analysis and design, continues with improvement, after improvement followed by verification and, of course, production line management.

\section{Human resource management as a factor of business process improvement}

Human resource management (HRM) refers to planning, finding, training and retaining a skilled workforce (Kahrović et al., 2020). It becomes crucial part of managerial activities, as it is aimed at insuring continuous development, achievement of business goals, but as well the motivation and satisfaction of needs and retention of competent human resources (Karabašević et al., 2016). This means that HRM realizes its impact through different mechanisms such as recruitment, job design, learning and development support and compensation and rewards (Jørgensen et al., 2007).

Role of people is identified as one of the critical factors of success or failure of BPI initiatives. That is why the training of staff for implementation of this kind of improvement initiatives is necessary in any type of organization (Börner et al., 2012). Knowledge and skills of employees are considered as basic resources that are necessary for BPI (Seethamraju, 2012). Johannsen and Fill (2017) highlight that the participation of employees in BPI projects is important because they possess the knowledge on potential problems and subsequently transform that knowledge into solutions. Their importance lies in their abilities to achieve goals set by their organizations by implementing the appropriate activities within business processes and providing value added products and services (Avakumović \& Avakumović, 2019).

Rosemann and vom Brocke (2015) characterize human resources as one of the core elements of business process management. Bhatti and Ahsan (2016) find that HRM practices, in global softer development environment, have positive impact on process improvement initiative. Within one of the more recent study authors Sardi et al. (2020) find that some SMEs consider HRM to be a key factor when it comes to the improvement of business performance.

\section{Business processes of textile and clothing industry MSMEs}

Processes of textile and clothing industry can be differently divided into groups. Fleacă and Purcărea (2014) state that, regardless of size, there are three main groups of processes: group of production processes, group of new product development processes and group of marketing processes. Production process represents a key process of manufacturing organizations within textile and clothing industry, and it is composed of large number of components (Chen et al., 2014; Paunović et al., 2019). Many operations of the production process within MSMEs are difficult or expensive to automate, manual work is still present in tasks such as creating, constructing, modeling, grading and fitting cut images, which in addition to long working hours of sewing machine operators makes this process labor intensive (Taplin et al., 2003; Gašović \& Ćurčić, 2018; Sarder et al., 2006). New product development process represents a creative process that consist of sample measures check, material type 
The impact of human resource management on business process improvement: an analysis within the MSMEs of the textile and clothing industry

check, analysis of production details, as well as fitting, appearance and comfort of new product (Powell \& Cassill, 2006; Bye \& LaBat, 2005). Group of marketing processes is focused on definition and satisfaction of consumer's needs (Utkun \& Atılgan, 2010). In conditions of limited resources, as it is the case within MSMEs, it is necessary to identify the ways in which it is possible to achieve wanted business results (Makedon et al., 2009). As Tudor (2018) stresses SMEs, as well as micro enterprises, face a turbulent business environment to which they are sensitive due to limited resources and challenges in relationships with their stakeholders. Business improvement initiatives, including BPI, should therefore take into account the specifics of business processes in line with the industry and the size of the organization.

\section{Research methodology}

Human resources are actively involved in the functioning of business processes, and as these resources are limited in MSMEs, managing them represents a significant research subject, especially in relation to the possibilities of improving business processes in conditions of limited human resources. The main goal of the research is to assess the impact of HRM on BPI of MSMEs in textile and clothing industry of Southern and Eastern Serbia. Accordingly, 210 respondents employed in MSMEs in the textile and clothing industry participated in the research. In order to adequately analyze the impact of HRM on the establishment of continuous BPI in the considered group of organizations, a questionnaire was formed consisting of part of general questions and two subscales that form a scale for assessment of the impact of HRM on BPI. The items of the subscales are graded on a five-point scale, with a score of 1 indicates strong disagreement and a score of 5 indicates absolute agreement. The first subscale is made up of claims related to the HRM in line with the focus on business processes, while the second consists of claims related to BPI activities. Such a structured scale for assessing the impact of HRM on BPI is motivated by scales used in previous research to analyze process orientation, establish business process management practices and improve business processes (McCormack, 2001; BosiljVukšić et al., 2008; Škrinjar \& Trkman, 2013; Dobrosavljević \& Urošević, 2020). Table 1 presents a scale according to which the defined impact is tested based on responses of employees in MSMEs of textile and clothing industry of Southern and Eastern Serbia.

Table 1. Scale for the assessment of impact of HRM on BPI in textile and clothing industry MSMEs

\begin{tabular}{ll}
\hline \multicolumn{1}{c}{ Subscale title } & Code \\
\hline Human resource management & HRM \\
\hline Human resources are continuously learning on job. & HRM1 \\
Human resources are prepared to use methods and techniques for BPI. & HRM2 \\
Human resources are prepared to manage new or improved business & HRM3 \\
processes. & HRM4 \\
Human resources are reliable and achieve the goals of business processes. & HRM5 \\
Recognized effort of human resources gets rewarded. & BPI \\
\hline Business process improvement & BPI1 \\
\hline Top management is actively involved in BPI efforts. & BPI2
\end{tabular}


BPI plans exist and they are driven by customer and operational strategies.

BPI3

Performance results are used to set the improvement goals.

BPI4

Customer feedback is used for systematic improvement of internal processes.

BPI5

Source: McCormack, 2001; Bosilj-Vukšić et al., 2008; Škrinjar \& Trkman, 2013;

Dobrosavljević \& Urošević, 2020

Gathered responses are statistically processed using the SPSS 20 program for statistical data analysis (Arbuckle, 2011). The general assumption that needs to be tested within research steps is that HRM represents a factor of strong and positive impact on BPI. First of all, analysis of descriptive statistics provides the insight into the general information about the respondents, such as the size of the organization in which they work, their position and gender. After the analysis of group of general question, the reliability and internal consistency of the scale and each of the subscales is performed using Cronbach's Alpha coefficient (Taber, 2018). After the reliability analysis the descriptive statistic of all items of the scale is provided. In order to achieve the research goal and analyze the impact of HRM on BPI the items of each subscale are transformed to create two variables: HRM and BPI variables. This transformation is done using the compute variable option within SPPS. Computed variables present the mean values of each subscale and the descriptive statistics is also provided upon transformation. The scatter diagram is constructed and correlation analysis between two transformed variables is then performed, to provide the insight into the strength and direction of a relationship between them (Greasley, 2007). As a final step that leads to the answer about the defined impact, the regression analysis is performed (Manasijević, 2016). ANOVA test within the regression analysis tests the null hypothesis $\left(\mathrm{H}_{0}\right)$ that the determination coefficient $\mathrm{R}$ Square in observed set is equal to zero i.e., that the linearity doesn't exist. Based on the results it is possible to provide the answer to the general assumption of the research and to achieve the research goal.

\section{Research results}

Using the descriptive statistics analysis, the first part of the questionnaire, dedicated to the general questions is assessed. Analysis of descriptive statistics provides the insight into general information about the respondents. Among 210 respondents there is 149 from micro, 48 from small, and 13 from medium enterprises. Regarding the respondent's position, $43.3 \%$ is in a managerial position or is the owner, $12.9 \%$ works in sales and 43.8 works in production. Within the sample there is $84.3 \%$ of female respondents and $15.7 \%$ of male respondents.

Internal consistency and reliability of formed scale and its subscales HRM and BPI is assessed using Cronbach's Alpha coefficient. The obtained values are presented within Table 2.

Table 2. Reliability of the scale and associated subscales HRM and BPI

\begin{tabular}{lcc}
\hline Subscale & Number of items & Cronbach's Alpha \\
\hline HRM & 5 & 0.869 \\
BPI & 5 & 0.852 \\
Total scale HRM-BPI & 10 & 0.920 \\
\hline
\end{tabular}

Source: Author's calculation based on SPSS 20 
Proposed cutoff value of Cronbach's Alfa coefficient, that is often used to determine the reliability of measurement scale, is 0.7 or 0.75 (Christmann \& Van Aelst, 2006; Bjertnaes et al., 2011). This means that the values presented in Table 2 indicate a high level of reliability of the subscales as well as the overall scale for measurement of the impact of HRM on BPI.

Each of the items of the scale is assessed using descriptive statistics analysis, as presented in Table 3.

Table 3. Descriptive statistics of scale items

\begin{tabular}{ccc}
\hline Item & Mean & Std. Deviation \\
\hline HRM1 & 3.4619 & 0.88094 \\
HRM2 & 3.2667 & 0.92044 \\
HRM3 & 3.1667 & 0.96138 \\
HRM4 & 3.5524 & 0.82984 \\
HRM5 & 3.3667 & 0.88789 \\
BPI1 & 3.8000 & 0.91662 \\
BPI2 & 3.0905 & 0.97156 \\
BPI3 & 3.3810 & 0.93195 \\
BPI4 & 3.6476 & 0.85259 \\
BPI5 & 3.4571 & 0.88072 \\
\hline
\end{tabular}

Source: Author's calculation based on SPSS 20

According to the presented mean values, within the Table 3, respondents demonstrate the highest level of agreement with the scale item BPI1 (3.8000), which refers to active involvement of top management (manager or owner) in efforts towards successful BPI. As descriptive statistics in earlier steps of analysis showed, a large number of respondents is in a managerial position or is the owner. Besides, the items that are rated with values above 3.5, i.e., with which the respondents agree are also BPI4 (performance results are used to set the improvement goals) and HRM4 (human resources are reliable and achieve the goals of business processes). The lowest level of agreement is with the scale item BPI2 (3.0905) which refers to addressing BPI and process redesign regularly on the management meetings. This means that this item is the least represented in MSMEs of textile and clothing industry of Southern and Eastern Serbia.

Next step of this research implies transformation of each subscale items into variables. Transformation is done using the compute variable option within SPSS 20 program. Using this option new variables are derived by calculating the mean value of each subscale. This provided variables HRM and BPI. Table 4 provides the descriptive statistics of transformed variables.

Table 4. Descriptive statistics of transformed variables HRM and BPI

\begin{tabular}{ccc}
\hline Variable & Mean & Std. Deviation \\
\hline HRM & 3.3629 & 0.72676 \\
BPI & 3.4752 & 0.72221 \\
\hline
\end{tabular}

Source: Author's calculation based on SPSS 20 
In order to advance to the final step of the research and test the defined hypothesis, the scatter diagram is constructed and presented on Figure 1, and the correlation analysis of the transformed variables is performed and presented within Table 5.

Figure 1. Scatter diagram

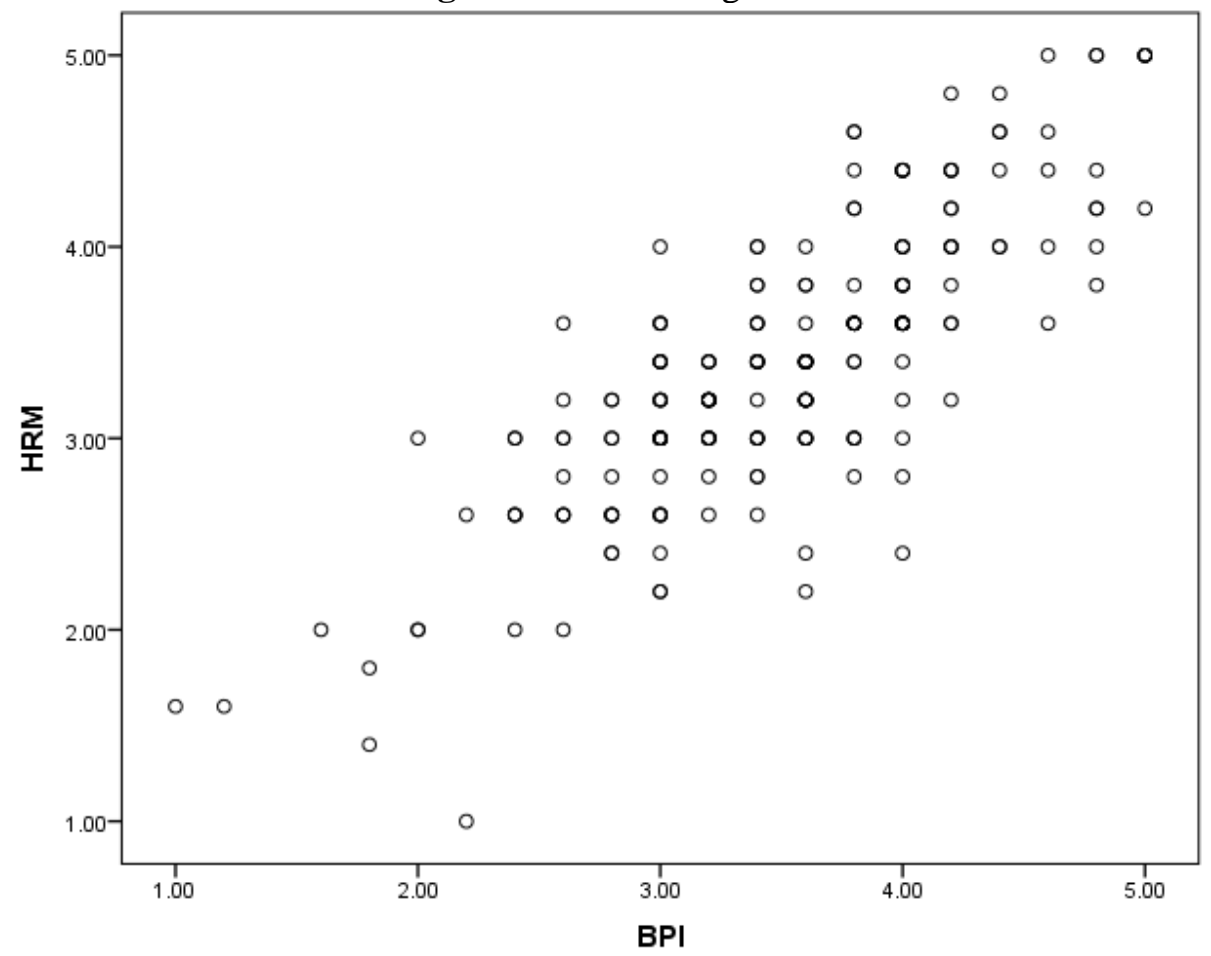

From the scatter diagram presented on the Figure 1 is visible that the correlation between two observed variables is strong and positive. As the linear connection is present Pearson correlation coefficient should be reported. Pearson correlation coefficient presents the measure of the strength of the relationship between two variables (Xu \& Deng, 2017).

Table 5. Correlations

\begin{tabular}{ccc}
\hline & HRM & BPI \\
\hline Pearson Correlation & 1 & $0.808^{* *}$ \\
HRM Sig. (2-tailed) & & 0.000 \\
Pearson Correlation & $0.808^{* *}$ & 1 \\
BPI Sig. (2-tailed) & 0.000 & \\
\hline $\mathrm{N}$ & 210 & 210 \\
\hline
\end{tabular}

${ }^{* *}$ Correlation is significant at the 0.01 level (2-tailed)

Source: Author's calculation based on SPSS 20

Based on the presented value of Pearson correlation coefficient it can be concluded that the strength of correlation is high. The coefficient of $0.808 * *$ is a positive number, which implies that the variables HRM and BPI are directly related (Mukaka, 2012). 
The impact of human resource management on business process improvement: an analysis within the MSMEs of the textile and clothing industry

The final step of the analysis implies the use of regression analysis. Regression analysis represents the method which provides the prediction and assessment of one of one phenomenon in relation to another (Manasijević, 2016). In this way the assumption HRM represents a factor of strong and positive impact on BPI is assessed. The results of performed regression analysis are presented in Tables 6-8.

Table 6. Model summary

\begin{tabular}{ccccc}
\hline Model & $\mathrm{R}$ & R Square & Adjusted R Square & $\begin{array}{c}\text { Std. Error of the } \\
\text { Estimate }\end{array}$ \\
\hline 1 & $0.808^{\mathrm{a}}$ & 0.653 & 0.652 & 0.42626 \\
\hline
\end{tabular}

a. Predictors: (Constant), HRM

Source: Author's calculation based on SPSS 20

Table 7. ANOVA ${ }^{\mathrm{a}}$

\begin{tabular}{llccccc}
\hline \multirow{2}{*}{ Model } & $\begin{array}{c}\text { Sum of } \\
\text { Squares }\end{array}$ & df & Mean Square & F & Sig. \\
\hline 1 & Regression & 71.218 & 1 & 71.218 & 391.963 & $0.000^{\mathrm{b}}$ \\
& Residual & 37.793 & 208 & 0.182 & & \\
& Total & 109.011 & 209 & & & \\
\hline
\end{tabular}

a. Dependent Variable: BPI

b. Predictors: (Constant), HRM

Source: Author's calculation based on SPSS 20

Table 8. Coefficients ${ }^{\mathrm{a}}$

\begin{tabular}{ccccccc}
\hline \multirow{2}{*}{ Model } & \multicolumn{2}{c}{$\begin{array}{c}\text { Unstandardized } \\
\text { coefficients }\end{array}$} & \multicolumn{2}{c}{$\begin{array}{c}\text { Standardized } \\
\text { Coefficients }\end{array}$} & T & Sig. \\
& & B & Std. Error & Beta & & \\
\hline 1 & (Constant) & 0.774 & 0.140 & & 5.547 & 0.000 \\
& HRM & 0.803 & 0.041 & 0.808 & 19.798 & 0.000 \\
\hline
\end{tabular}

a. Dependent Variable: BPI

Source: Author's calculation based on SPSS 20

Based on the presented results, the equation of the linear regression reads: $\mathrm{BPI}=0.774+0.803(\mathrm{HRM})$. The ANOVA table presents the results of null hypothesis testing, which reads that the determination coefficient $\mathrm{R}$ Square in observed set is equal to zero i.e., the linearity doesn't exist. As the value of F statistics is 391.963 and the realized level of significance (Sig.) is 0.000 , which is lower than 0.01 , the null hypothesis about the non-existence of linear connection between HRM and BPI variables is rejected, and the statistical significance of assessed linear model is confirmed. The percent of the variation of BPI is explained by variations of HRM is 0.653 , therefore there is $65.3 \%$ of variation.

According to the results of conducted analyses, the general assumption, which is: "HRM represents a factor of strong and positive impact on BPI", is confirmed. Based on that, it can be concluded that better HRM activities lead to the more successful BPI initiatives in MSMEs of textile and clothing industry in Southern and Eastern Serbia, according to the answers provided by employees. 


\section{Conclusion}

Using the SPSS software package for statistical data processing, data from a sample of 210 employees in MSME organizations of the textile and clothing industry of Southern and Eastern Serbia were processed. The research points out that respondents agree that the owner/manager is actively involved in efforts to improve business processes, that the results of the achieved process performance are used to set a new set of targeted performance, and that employees are reliable and can be counted on in the implementation of BPI initiatives. The transformation of items from the subscale into two variables whose influence is being examined, variables HRM and BPI, was performed. A positive and strong correlation between these variables was established and then the pre - defined basic assumption of the research was examined. Assumption that HRM represents a factor of strong and positive impact on BPI in textile and clothing industry MSMEs is confirmed. This result also confirms that the importance of adequate HRM practice is recognized. Future research is going to be focused on more detailed analysis of influence of established characteristics of MSME within the textile and clothing industry such as limited resources and work intensity on the application of business practices and various business initiatives, and the development of an adequate model for solving possible problems in implementation, which may arise from these characteristics.

\section{References}

Arbuckle, J. L. (2011). IBM SPSS Amos 20 user's guide. Amos Development Corporation, SPSS Inc.

Avakumović, J., \& Avakumović, J. (2018). Menadžment, ljudski resursi i novi trendovi poslovanja u tekstilnoj industriji, Tekstilna industrija, 66(3), 47-51.

Bakotic, D., \& Krnic, A. (2017). Exploring the relationship between business process improvement and employees' behavior. Journal of organizational change management, 30(7), 1044-1062. https://doi.org/10.1108/JOCM-06-2016-0116

Battaglia, M., Testa, F., Bianchi, L., Iraldo, F., \& Frey, M. (2014). Corporate social responsibility and competitiveness within SMEs of the fashion industry: Evidence from Italy and France. Sustainability, 6(2), 872893. https://doi.org/10.3390/su6020872

Beerepoot, I., van de Weerd, I., \& Reijers, H. A. (2019). Business process improvement activities: differences in organizational size, culture, and resources. In International Conference on Business Process Management (pp. 402-418). Springer, Cham.

Bhatti, M. W., \& Ahsan, A. (2016). Global software development: an exploratory study of challenges of globalization, HRM practices and process improvement. Review of Managerial Science, 10(4), 649-682. https://doi.org/10.1007/s11846-015-0171-y

Bjertnaes, O. A., Lyngstad, I., Malterud, K., \& Garratt, A. (2011). The Norwegian EUROPEP questionnaire for patient evaluation of general practice: data quality, reliability and construct validity. Family practice, 28(3), 342-349. https://doi.org/10.1093/fampra/cmq098

Bosilj-Vukšić, V., Hernaus, T, Kovačić, A. (2008). Upravljanje poslovnim procesima - organizacijski i informacijski pristup. Školska knjiga. 
Börner, R., Moormann, J., \& Wang, M. (2012). Staff training for business process improvement. Journal of Workplace Learning, 24(3), 200-225. https://doi.org/10.1108/13665621211209276

Brajer-Marczak, R. (2014). Employee engagement in continuous improvement of processes. Management, 18(2), 88-103. https://doi.org/10.2478/manment2014-0044

Buckler, B. (1996). A learning process model to achieve continuous improvement and innovation. The Learning Organization, 3(3), 31-39. https://doi.org/10.1108/09696479610119660

Bye, E., \& LaBat, K. (2005). An Analysis of Apparel Industry Fit Sessions. Journal of Textile and Apparel, Technology and Management, 4(3), 1-5.

Chen, J. C., Chen, C. C., Lin, Y. J., Lin, C. J., \& Chen, T. Y. (2014). Assembly Line Balancing Problem of Sewing Lines in Garment Industry. Proceedings of the 2014 International Conference on Industrial Engineering and Operations Management, 1215-1225.

Christmann, A., \& Van Aelst, S. (2006). Robust estimation of Cronbach's alpha. Journal of Multivariate Analysis, 97(7), 1660-1674. https://doi.org/10.1016/j.jmva.2005.05.012

Damij, N., Damij, T., Grad, J., \& Jelenc, F. (2008). A methodology for business process improvement and IS development. Information and software technology, 50(11), 1127-1141. https://doi.org/10.1016/j.infsof.2007.11.004

Demirbag, M., Koh, S. L., Tatoglu, E., \& Zaim, S. (2006). TQM and market orientation's impact on SMEs' performance. Industrial Management \& Data Systems, 106(8), 1206-1228. https://doi.org/10.1108/02635570610710836

Demirbas, D., Hussain, J. G., \& Matlay, H. (2011). Owner-managers' perceptions of barriers to innovation: empirical evidence from Turkish SMEs. Journal of Small Business and Enterprise Development, 18(4), 764-780. https://doi.org/10.1108/14626001111179794

Dobrosavljević, A. (2019). Managing the creative and labor-intensive business processes of the apparel industry. Tekstilna industrija, 67(4), 58-66. https://doi.org/10.5937/tekstind1904058D

Dobrosavljević, A., Urošević, S. (2020). Prioritization of key activities on establishment of BPM practice in Apparel Organizations, Textil ve Konfeksiyon, 30(3),

190-199. https://doi.org/10.32710/tekstilvekonfeksiyon.672312

Fleacă, E., \& Purcărea, A. A. (2014). Raising the competitiveness of Romanian enterprises acting in textile industry based on process management modeling. Industria Textila, 65(1), 47-52.

Iqbal, J., Ahmad, R. B., Nasir, M. H. N. M., Niazi, M., Shamshirband, S., \& Noor, M. A. (2016). Software SMEs' unofficial readiness for CMMI®-based software process improvement. Software Quality Journal, 24(4), 997-1023. https://doi.org/10.1007/s11219-015-9277-3

Gašović, M., \& Ćurčić, N. (2018). Efekti marketinga i dizajna primenom CAD sistema u kompanijama - proizođačima odeće. Vojno delo, 6, 309-320.

Gowen II, C. R., \& Johnson, J. M. (2011). Business process improvement: A key to equipment financing company competitiveness. Journal of Equipment Lease Financing, 29(3), 1-11. 
Greasley, P. (2007). Quantitative data analysis using SPSS: an introduction for health \& social science. McGraw-Hill Education (UK).

Holland, P., Sheehan, C., \& De Cieri, H. (2007). Attracting and retaining talent: Exploring human resources development trends in Australia. Human Resource Development International, 10(3), 247-262. https://doi.org/10.1080/13678860701515158

Holtzman, Y. (2011). Business process improvement and the tax department. The Journal of Management Development, 30(1), 49-60. https://doi.org/10.1108/02621711111098361

Hu, Q., Williams, S., Mason, R., \& Found, P. (2019). Knowledge management in consultancy-involved process improvement projects: cases from Chinese SMEs. Production Planning \& Control,30(10-12), 866-880. https://doi.org/10.1080/09537287.2019.1582095

Jørgensen, F., Laugen, B. T., \& Boer, H. (2007). Human resource management for continuous improvement. Creativity and Innovation Management, 16(4), 363 375. https://doi.org/10.1111/j.1467-8691.2007.00452.x

Kahrović, E., Ćorović, E., \& Dobardžić, A. (2020). Proces upravljanja ljudskim resursima u tekstilnoj industriji - studija slučaja novopazarskih preduzeća. Tekstilna industrija, 68(1), 36-45. https://doi.org/10.5937/tekstind2001036K

Karabašević, D., Stanujkić, D., Urošević, S., \& Maksimović, M. (2016). An approach to personnel selection based on Swara and Waspas methods. Bizinfo (Blace) Journal of Economics, Management and Informatics, 7(1), 1-11. https://doi.org/10.5937/bizinfo1601001K

Lee, K. T., \& Chuah, K. B. (2001). A SUPER methodology for business process improvement-An industrial case study in Hong Kong/China. International Journal of Operations \& Production Management, 21(5-6), 687-706. https://doi.org/10.1108/01443570110390408

Makedon, V., Hetman, O., Yemchuk, L., Paranytsia, N., Petrovska, S. (2019). Human resource management for secure and sustainable development. Journal of Security and Sustainability Issues, 8(3), 345-354. http://doi.org/10.9770/jssi.2019.8.3(5)

Manasijević, D. (2016). Teorijske osnove za izradu master rada. Tehnički fakultet u Boru.

Manfreda, A., Kovacic, A., Štemberger, M. I., \& Trkman, P. (2014). Absorptive capacity as a precondition for business process improvement. Journal of Computer Information Systems, 54(2), 35-43. https://doi.org/10.1080/08874417.2014.11645684

McAdam, R. (1996). An integrated business improvement methodology to refocus business improvement efforts. Business Process Re-engineering \& Management Journal, 2(1), 63-71. https://doi.org/10.1108/14637159610111482

McGovern, T., Small, A., \& Hicks, C. (2017). Diffusion of process improvement methods in European SMEs. International Journal of Operations \& Production Management, 37(5), 607-629. https://doi.org/10.1108/IJOPM-11-2015-0694

McCormack, K. (2001). Business process orientation: Do you have it?, Quality Progress, 34(1), 51-58. 
Mohammady Garfamy, R. (2011). Supplier selection and business process improvement: an exploratory multiple case study. International Journal of Operational Research, 10(2), 240-255. https://doi.org/10.1504/IJOR.2011.038586

Mukaka, M. M. (2012). A guide to appropriate use of correlation coefficient in medical research. Malawi Medical Journal, 24(3), 69-71.

Park, Y. I., \& Anderson, K. (1991). The rise and demise of textiles and clothing in economic development: the case of Japan. Economic Development and Cultural Change, 39(3), 531-548.

Paunović, D., Stojanović, O., \& Zlatev, Z. (2019). Kontrola kvaliteta odeće primenom AQL metode. Tekstilna industrija, 67(3), 22-28. https://doi.org/10.5937/tekstind1903022P

Pazilov, G. A., Ivashchenko, N. P., Bimendiyeva, L. A., \& Aitymbetova, A. N. (2020). Textile industry: issues of managing the growth of innovative activity in enterprises. Polish Journal of Management Studies, 21(1), 297-315. http://dx.doi.org/10.17512/pjms.2020.21.1.22

Powell, N. B., \& Cassill, N. L. (2006). New textile product development: Processes, practices, and products. Journal of the textile institute, 97(2), 155-166. https://doi.org/10.1533/joti.2005.0154

Rashid, O. A., \& Ahmad, M. N. (2013). Business process improvement methodologies: an overview. Journal of Information System Research Innovation, 5, 45-53.

Rosemann, M., \& vom Brocke, J. (2015). The six core elements of business process management. In Handbook on business process management 1 (pp. 105-122). Springer.

Saleh, A. S., \& Ndubisi, N. O. (2006). An evaluation of SME development in Malaysia. International Review of Business Research Papers, 2(1), 1-14.

Sallos, M. P., Yoruk, E., \& García-Pérez, A. (2017). A business process improvement framework for knowledge-intensive entrepreneurial ventures. The Journal of Technology Transfer, 42(2), 354-373. https://doi.org/10.1007/s10961-0169534-z

Sarder, M. B., Imrhan, S. N., \& Mandahawi, N. (2006). Ergonomic workplace evaluationof an Asian garment-factory. Journal of Human Ergology, 35(1-2), 45-51. https://doi.org/10.11183/jhe1972.35.45

Sardi, A., Sorano, E., Garengo, P., \& Ferraris, A. (2020). The role of HRM in the innovation of performance measurement and management systems: a multiple case study in SMEs. Employee Relations: The International Journal. https://doi.org/10.1108/ER-03-2020-0101

Schenkel, M. T., Farmer, S., \& Maslyn, J. M. (2019). Process improvement in SMEs: The impact of harmonious passion for entrepreneurship, employee creative selfefficacy, and time spent innovating. Journal of Small Business Strategy, 29(1), 71-84.

Seethamraju, R. (2012). Business process management: a missing link in business education. Business Process Management Journal, 18(3), 532-547. https://doi.org/10.1108/14637151211232696 
Slović, D., Stojanović, D., \& Tomašević, I. (2015). Productivity upswing through twophase continuous process improvement model: the case of apparel manufacturer. Tekstil ve Konfeksiyon, 25(2), 89-96.

Statistical Office of the Republic of Serbia. (2018). Statistical Yearbook of the Republic of Serbia, 2018. Statistical Office of the Republic of Serbia https://publikacije.stat.gov.rs/G2018/Pdf/G20182051.pdf

Taber, K. S. (2018). The use of Cronbach's alpha when developing and reporting research instruments in science education. Research in Science Education, 48(6), 1273-1296. https://doi.org/10.1007/s11165-016-9602-2

Taplin, I. M., Winterton, J., \& Winterton, R. (2003). Understanding Labour Turnover in a Labour Intensive Industry: Evidence from the British Clothing Industry. Journal of Management Studies, 40(4), 1021-1046. https://doi.org/10.1111/1467-6486.00369

Tudor, L. (2018). Change in textile and clothing industry. Industria Textila, 69(1), 3743.

Utkun, E., \& Attlgan, T. (2010). Marketing innovation in the apparel industry: Turkey. Fibres \& Textiles in Eastern Europe, 18(6), 26-31.

Škrinjar, R., Trkman, P. (2013). Increasing process orientation with business process management: Critical practices', International Journal of Information Management, 33, 48-60. https://doi.org/10.1016/j.ijinfomgt.2012.05.011

$\mathrm{Xu}$, H., \& Deng, Y. (2017). Dependent evidence combination based on shearman coefficient and pearson coefficient. IEEE Access, 6, 1163411640. https://doi.org/10.1109/ACCESS.2017.2783320

Rad je primljen: 15.12.2020; Prihvaćen: 24.12.2020.

Received: 15 December, 2020; Accepted: 24 December, 2020 